\title{
Concepts for Sustainable Landscape Mosaics ${ }^{1}$
}

\author{
Tina Mclntyre, Rachel Gutner, and Sandra Wilson²
}

\section{Introduction}

Florida is rapidly urbanizing, and with more and more new residents and businesses arriving daily, Florida's water resources may become limited in the future. If Florida continues to develop on trend, more than one-third of Florida's land will be developed by 2070 (UF GeoPlan Center et al. 2017). Nationwide, landscape irrigation is estimated to account for nearly one-third of all residential water use (EPA 2017). In order to be a steward of Florida's natural resources, it is important to create landscapes that do not use excessive amounts of water, fertilizer, pesticides and other resources. The concepts of Florida-Friendly Landscaping $^{\text {tm }}$ have been around since 1991 and continue to offer sustainable landscaping principles, including what is outlined in this document. This EDIS publication is for Florida homeowners, residential and commercial property managers, and landscape architects interested in creating aesthetically pleasing landscapes and to help individuals choose the right plant for the right place.

This document considers the need for sustainable landscaping in Florida, as well as the desire for aesthetically pleasing landscapes. As proposed by Piet Oudolf, a prominent Dutch garden designer, there is beauty in all seasons, and the dieback of a plant, if placed properly, can add to the overall effect of the garden. In this publication, we define a mosaic as a landscape composed of plants that bloom at specific times, have seasonality (including dieback), and exhibit different textures, shapes, and sizes. One can create a mosaic image of sustainable landscaping by selecting and utilizing Florida-friendly and native plants.

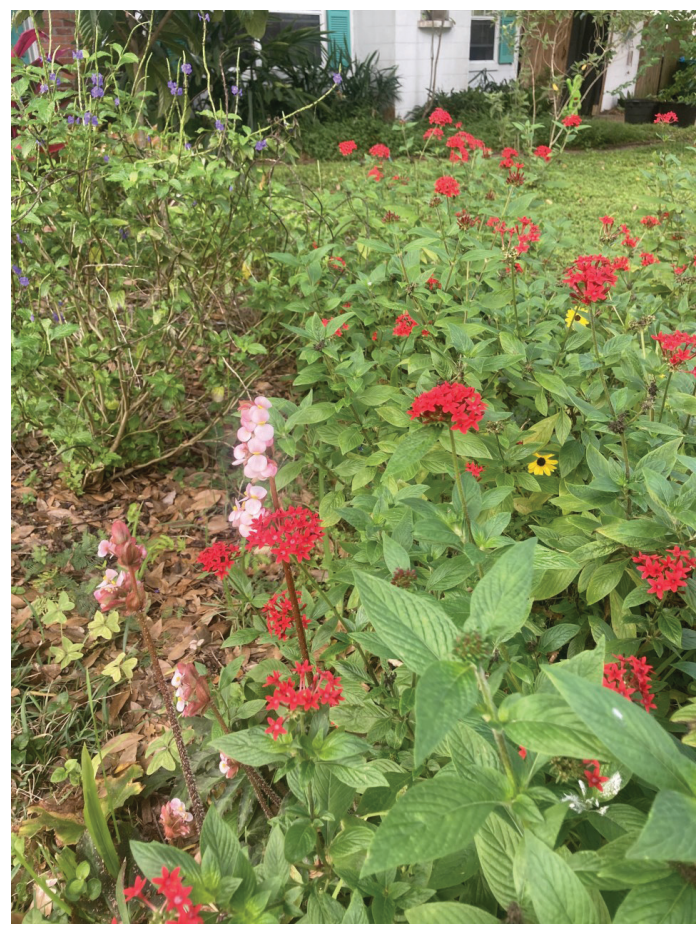

Figure 1. Pentas lanceolata (red) is interspersed with Helianthus debilis (yellow) and Stachytarpheta jamaicensis (purple) in the front yard of a residential home.

Credits: Tina McIntyre, UF/IFAS

Landscaping offers a great opportunity for homeowners to mimic Florida's beautiful natural environments and incorporate water-wise plant selections into their designs. We've created two primary mosaic concepts that embrace and highlight a certain theme. They include the pollinator concept and the seasonal concept, which can be used separately or combined to help landscapers, homeowners,

1. This document is ENH1341, one of a series of the Environmental Horticulture Department, UF/IFAS Extension. Original publication date June 2021. Visit the EDIS website at https://edis.ifas.ufl.edu for the currently supported version of this publication.

2. Tina McIntyre, Florida-Friendly Landscaping ${ }^{\mathrm{TM}}$ Agent, UF/IFAS Extension Seminole County; Rachel Gutner, undergraduate student, University of Central Florida; and Sandra Wilson, professor, Environmental Horticulture Department, UF/IFAS Extension, Gainesville, FL 32611.

The Institute of Food and Agricultural Sciences (IFAS) is an Equal Opportunity Institution authorized to provide research, educational information and other services

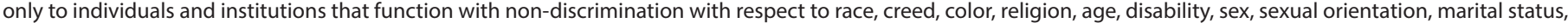

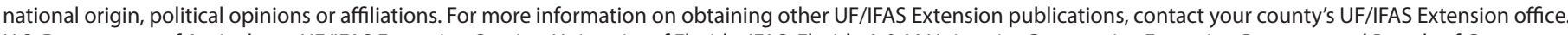
U.S. Department of Agriculture, UF/IFAS Extension Service, University of Florida, IFAS, Florida A \& M University Cooperative Extension Program, and Boards of County Commissioners Cooperating. Nick T. Place, dean for UF/IFAS Extension. 
landscape architects, and HOAs (homeowners' associations) responsibly choose appealing plants to meet that conceptual goal.

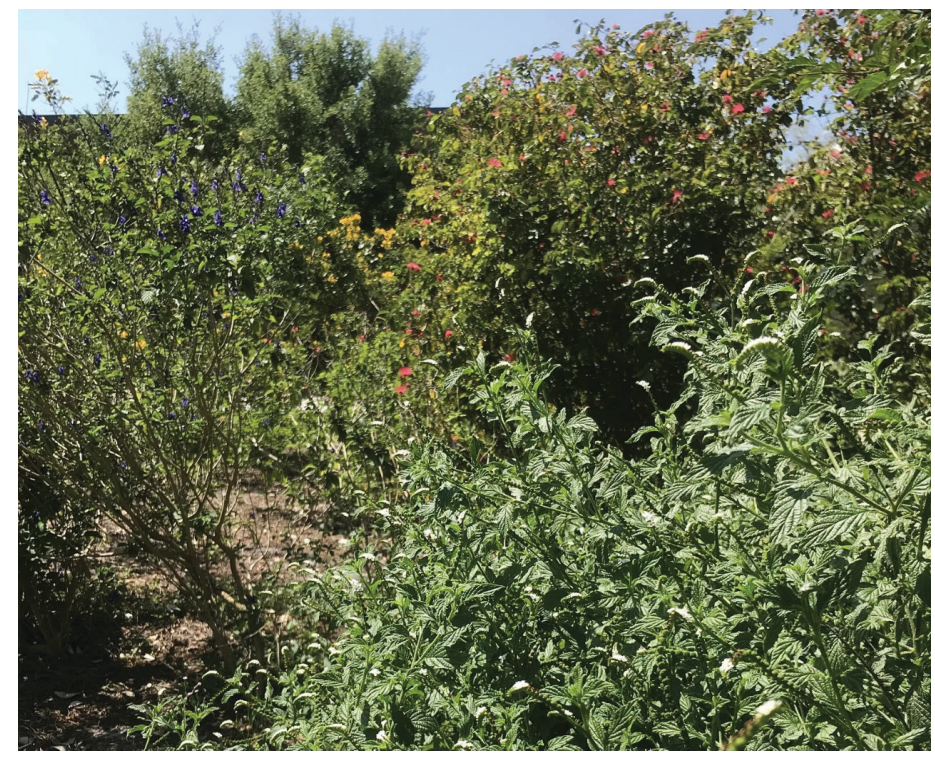

Figure 2. Scorpion tail, Heliotropium angiospermum, in the front of the mosaic garden, with Calliandra hematocephala (pink), Stachytarpheta frantzii (purple), and Senna mexicana var. chapmanii (yellow) in the background.

Credits: Rachel Gutner, UF/IFAS

Green spaces, such as residential yards, commercial properties, and shared communal parks, enrich our lives in many different ways. Horticulture is linked to improved mental health, improved human performance and energy, reduced stress, and much more. There are also economic benefits to investing in green spaces, such as reduced healthcare costs and increased property values. Green spaces reduce noise pollution and stormwater runoff and help to improve water quality by absorbing nutrients from pet waste, excess landscape fertilizers, and toxic organic chemicals such as pesticides before they enter surrounding waterways. They also reduce heat and cold damage in urban areas (International Society for Horticultural Science 2012). By embracing these plant concepts and proposed species in your yard, managed area, or shared space, you and your community can actualize these mental, physical, and financial benefits.

\section{Site Preparation and Management}

The best way to control weeds is to prepare your land effectively prior to installation. With a little time and planning, you can manage weeds by solarizing the area (McSorley and Gill 2019). Solarize your garden space by removing as much of the existing undesired plants as you can, then wet the soil thoroughly. Cover the area with $1 \mathrm{ml}$ thick polyethylene (PE) heavy-duty clear plastic and secure the edges with landscape ties or soil to trap heat, prevent photosynthesis, and smother the remaining unwanted plants or seeds. Leave this covering on for about six to eight weeks. When you remove the plastic, all the roots of the weeds in the upper 4" 6 " of soil should be dead. Because this treatment only targets the upper part of the soil, deeper soil may still be affected by pests, and after 3-4 months, the effects of solarization diminish (McSorley and Gill 2019).

Soil tests, which can be sent to the UF/IFAS Extension Soil Testing Laboratory (ESTL), will help determine the site conditions most accurately. See the $\mathrm{pH}$ column in Table 1 below to determine if the selected plants will do well in your site. Most plants will benefit from soil enhancement, but native plants are particularly well suited to sandy soil and acidic conditions. If you wish to enhance your soil, we recommend mixing organic material into the existing soil during this phase (Treadwell et al. 2019).

Although native plants typically require less maintenance and fewer resources, it is virtually impossible to create a landscape with no maintenance. Weed control (including invasive species removal) is important to maintaining the aesthetics of a landscape. However, before weeds can be controlled, they must be identified. Landscape managers or property owners should identify the weed and determine if it is problematic before removing it. Some weeds, if not invasive, might be a good addition to the landscape, depending on its purpose. To identify a plant you are unfamiliar with, visit the UF/IFAS Weed Identification Guide, submit a specimen to your local Master Gardener Volunteer program, or submit a specimen to the Distance Diagnostic and Identification System.

After planting, two to three inches of mulch should be applied to the landscape to suppress weed germination, hold moisture in the root zone, prevent erosion and provide aesthetic uniformity. Pine needles and other leaves are a sustainable selection while being readily available most of the year. Lightly pruning plants at certain times of the year will help regenerate growth and promote blooms. Plant replacement might also be necessary if some plants fail to thrive due to natural causes.

\section{Pollinator Concept}

A pollinator is any animal that helps carry pollen from the male part of the flower to the female part of the same or another flower. Pollination must occur for the plants to become fertilized and produce fruits, seeds, and young plants. The relationship between pollinators and plants is one of the oldest and most striking symbiotic relationships that still exists today. This symbiosis can be observed in your yard: hummingbirds are naturally drawn to the 
reddish flowers of coral porterweed, Stachytarpheta mutabilis, and their long tongues are perfectly adapted to the long broad tubes of the flower, which lead to a high nectar reward. Hummingbirds pollinate by tending to plants with long nectaries: as they forage for nectar, pollen sticks to their beaks and faces and spreads to other plants. Through this relationship, pollinators feed and the female plant parts are fertilized. If successful, plant pollination leads to seeds that, when germinated, differ genetically from the parent. Further, the leaves of some pollinator plants may serve as food for the larval stages (i.e., caterpillars) of certain butterflies and some insects. Plants that also function as larval host plants are designated in the plant matrix. This dance and relationship that is mutually beneficial and reciprocal carries the species involved through time and space.

Pollinators are essential to human existence; their efforts contribute to a third of all food that humans eat. Even if pollinators are not directly pollinating human food crops, those plants often feed other organisms that we depend on. Pollinators also contribute greatly to healthy ecosystems because they transport pollen to plants that stabilize our soil, clean our air, supply oxygen, and support wildlife.

It is important to provide a habitat oasis to native and nonnative pollinators, such as bees, butterflies, and wasps. Some birds and hummingbirds are also effective pollinators. Many birds consume the fruits and excrete the seeds, which spreads the plant offspring. By creating a pollinator-focused landscape, you create a refuge for these vital creatures. Table 1 outlines many plant species that are suitable for pollinator gardens, with host species denoted by a dagger. Additionally, mobile web applications, such as the FFL Plant Guide, are available to assist with choosing native and nonnative pollinator plants and to learn about Florida's diverse butterfly (https://ffl.ifas.ufl.edu/butterflies) and bee pollinators (https://ffl.ifas.ufl.edu/bees).

Because this concept focuses on wildlife, it is important not to use harsh chemicals when managing weeds. Some chemicals and common weed killers can also kill some species of bees, particularly honeybees (McSorley and Gill 2019).

\section{Seasonal Concept}

Florida's natural ecosystems typically have a colorful display in fall and spring. Table 1 offers a list of plants that bloom by season. The "Year-Round" section contains plants that bloom throughout the year.
Because the list is primarily organized by bloom period, landscapers and homeowners also have the option of creating a colorful seasonal landscape. Florida's unique, semitropical environment creates a hotbed of plants that respond to seasonal changes. These plants can make for an eye-catching yard full of blooms up to 6 months out of the year. We encourage landscapers and homeowners to explore the idea of nature-inspired, seasonally based landscapes because they highlight Florida's many attractive plants. With the tendency for seasonally interesting plants to die back, many plants that are listed provide strong structural integrity with evergreen foliage.

\section{Plant Matrix}

Listed here are Florida-friendly plants organized by seasonal bloom period. All plants in this list are pollinator plants, meaning that their blooms provide a significant source of either nectar or pollen. Some of the species also function as host plants, providing food and resources for the larval stages of adult pollinators. The growing information for each plant is included, such as USDA hardiness zones, $\mathrm{pH}$ preference, light and moisture preferences, native status, and perennial/annual condition.

Because all annuals selected reseed, the homeowner/ groundskeeper does not have to worry about replacing the entire section when the plant dies back. Some perennials, marked with an asterisk, also reseed, but not as prolifically.

Special thanks to Dr. Timur Momol, District Director for UF/IFAS Extension Central District, for funding and inspiration for this project.

\section{References}

Arnett, J. 2014. "Coevolution and Pollination."

Douglasia 38 (2). https://www.wnps.org/blog/ coevolution-and-pollination

Cornwall, W. 2018. “Common Weed Killer-Believed Harmless to Animals-May Be Harming Bees Worldwide." Science (September 24, 2018). https://doi.org/10.1126/ science.aav5169

Dave’s Garden. 2021. "Plant Files.” https://davesgarden. com/guides/pf/

Davies, F., R. Geneve, and S. B. Wilson. 2018. Hartmann and Kester's Plant Propagation: Principles and Practices, 9th edition. New York: Pearson Education Inc. 
Elmore, C. L., J. J. Stapleton, C. E. Bell, and J. E. Devay. 1997. Soil Solarization: A Nonpesticidal Method for Controlling Diseases, Nematodes, and Weeds. Publication 21377. University of California, Division of Agriculture and Natural Resources. https://vric.ucdavis.edu/pdf/soil_solarization.pdf

EPA. 2017. "Outdoor Water Use in the United States." https://19january2017snapshot.epa.gov/www3/watersense/ pubs/outdoor.html

Florida Native Plants Nursery. n.d. https://floridanativeplants.com/

International Society for Horticultural Science. 2012. "Health and Wellbeing." In Harvesting the Sun: A Profile of World Horticulture, 50-57. http://www.harvestingthesun. org/

McSorley, R., and H. K. Gill. 2019. "Introduction to Soil Solarization.” EDIS 2010 (4). https://edis.ifas.ufl.edu/ publication/IN856

Missouri Botanical Garden. n.d. Plant Finder. https://www. missouribotanicalgarden.org/plantfinder/plantfindersearch. aspx

Motta, E. V. S., K. Raymann, and N. A. Moran. 2018. "Glyphosate Perturbs the Gut Microbiota of Honey Bees." PNAS 115 (41): 10305-10310. https://doi.org/10.1073/ pnas. 1803880115

National Park Service. 2018. "What Is a Pollinator?" https:// www.nps.gov/subjects/pollinators/what-is-a-pollinator.htm

Treadwell, D. D., S. P. Brown, J. Stephens, and S. Webb. 2019. "Organic Vegetable Gardening in Florida." EDIS 2013 (6). https://doi.org/10.32473/edis-hs1215-2013

UF GeoPlan Center, 1000 Friends of Florida, and Florida Department of Agriculture and Consumer Resources. 2017. "What Is Your Vision for Florida's Future?" 2070 Report. https://1000friendsofflorida.org/florida2070/wp-content/ uploads/2017/08/FOF-1080-Newsletter-Spring-2017-v12web.pdf

UF/IFAS Gardening Solutions. 2013. "Working in Your Florida Soil.” https://gardeningsolutions.ifas.ufl.edu/care/ planting/florida-soil.html

USDA, NRCS. 2021. The PLANTS Database. National Plant Data Team, Greensboro, NC. https://plants.sc.egov.usda. gov/java/

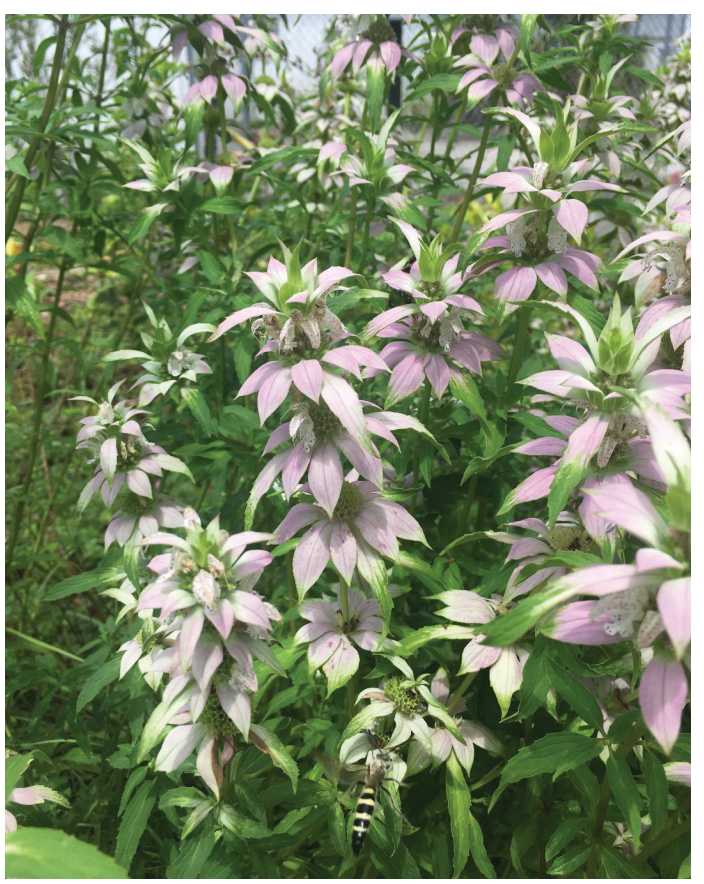

Figure 3. Colorful bracts of spotted bee balm (Monarda puntata) and floral visitation by a wasp pollinator.

Credits: Tina McIntyre, UF/IFAS

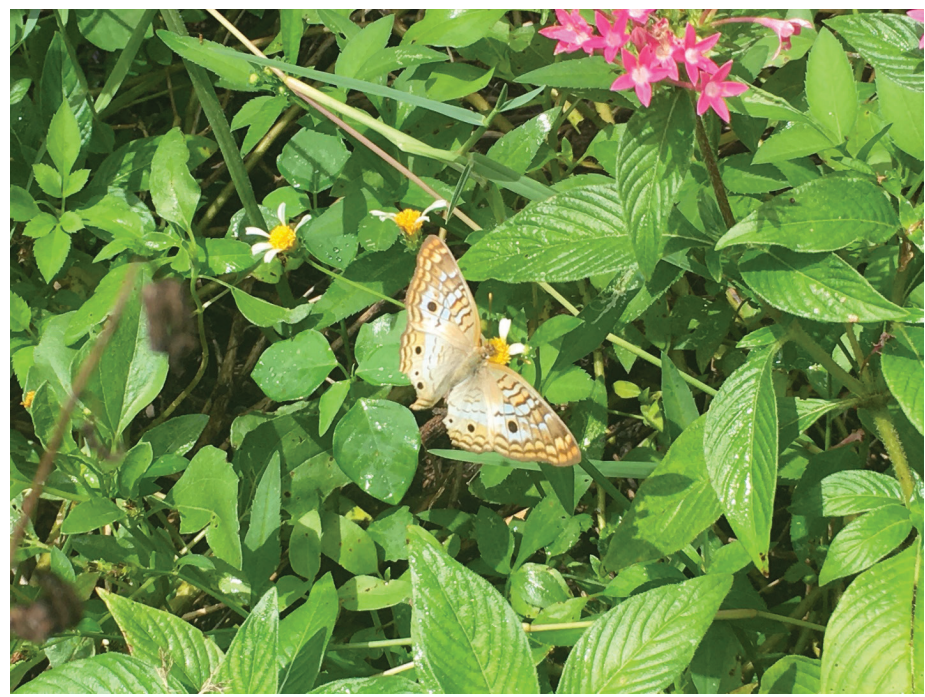

Figure 4. Pollinator on Bidens alba, which is typically targeted as a weed but can be a good source for pollinators. Also pictured, Pentas lanceolata.

Credits: Tina McIntyre, UF/IFAS 


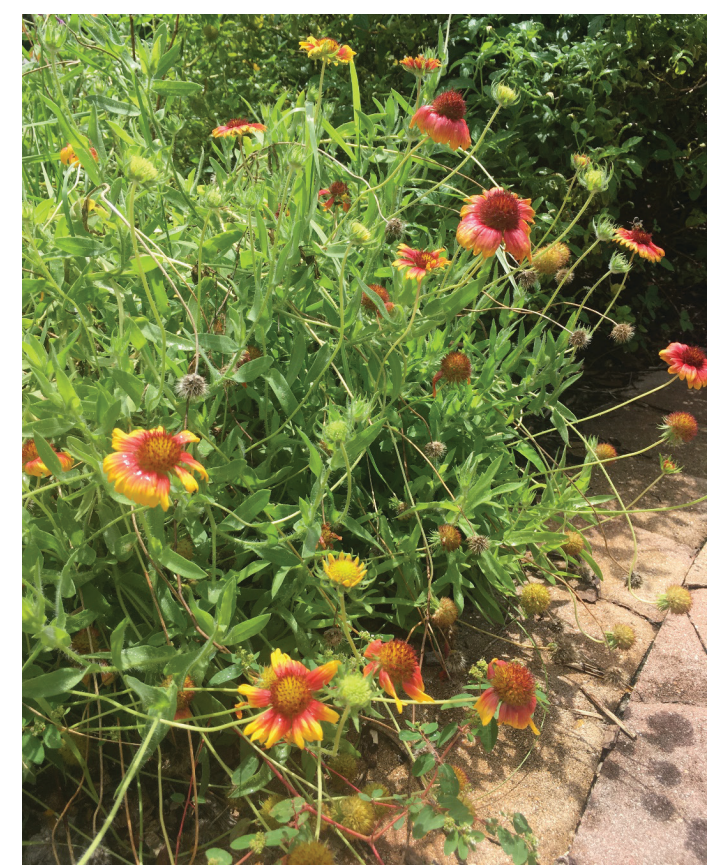

Figure 5. Gaillardia pulchella providing great ground coverage for soil and habitat for pollinators.

Credits: Tina McIntyre, UF/IFAS

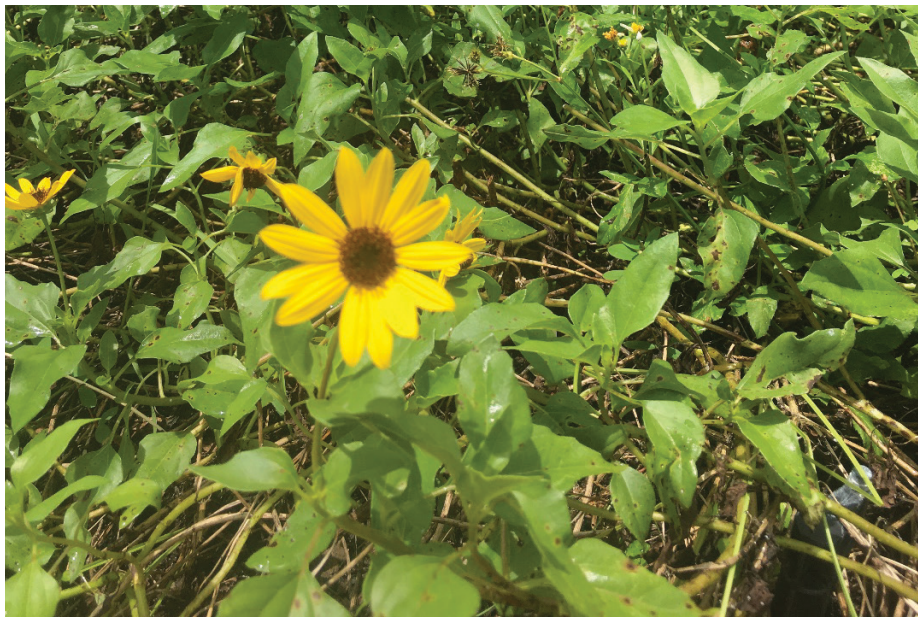

Figure 6. Rapidly growing dune sunflower, Helianthus debilis.

Credits: Tina Mclntyre, UF/IFAS

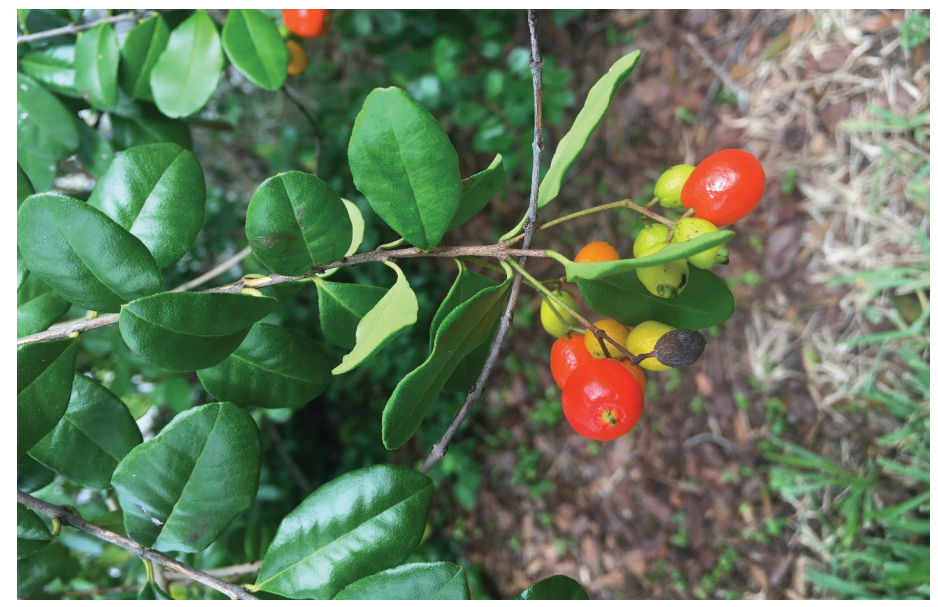

Figure 7. Berries and leaves of the native Simpson's stopper,

Myrcianthes fragrans.

Credits: Tina Mclntyre, UF/IFAS

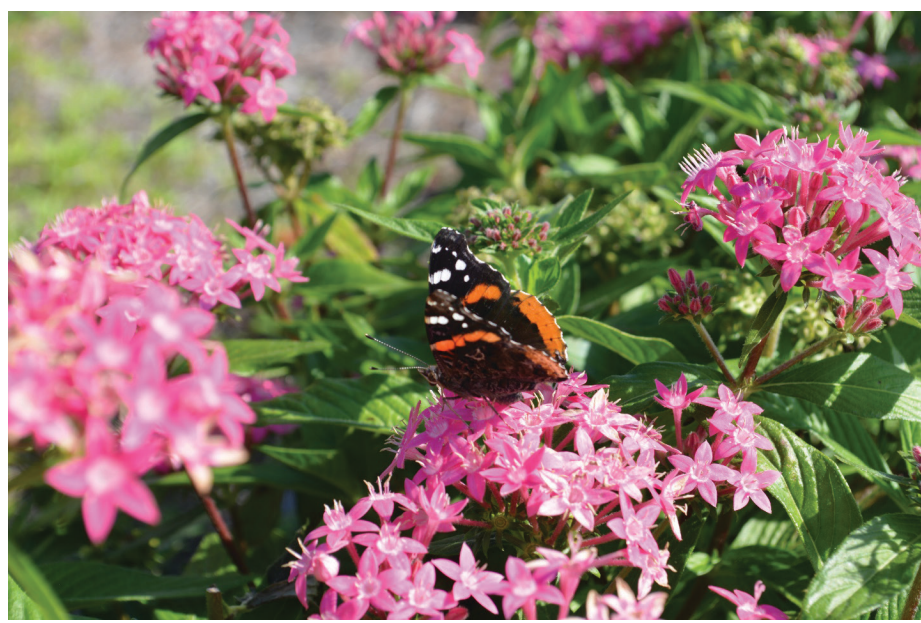

Figure 8. Butterfly on Pentas lanceolata.

Credits: Tina McIntyre, UF/IFAS

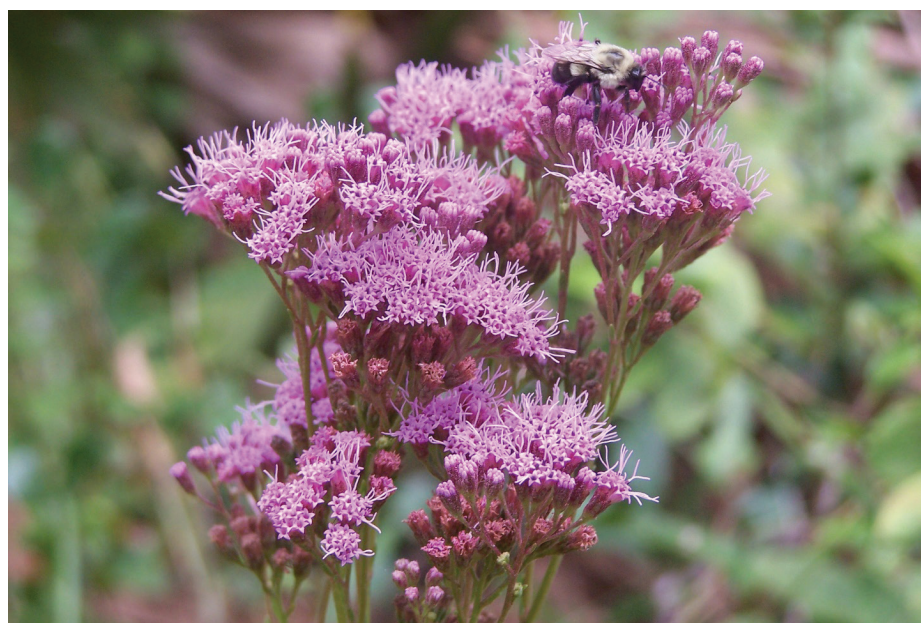

Figure 9. Bumble bee on hairy chaffhead, Carphephorus paniculatus.

Credits: Tina McIntyre, UF/IFAS

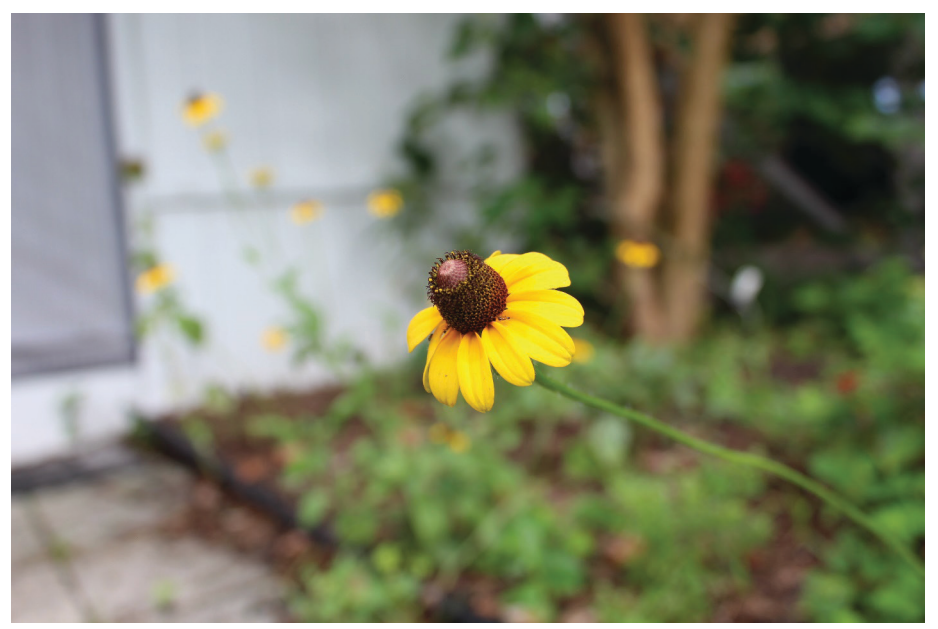

Figure 10. Rudbeckia sp. cultivated in a backyard.

Credits: Tina McIntyre, UF/IFAS 


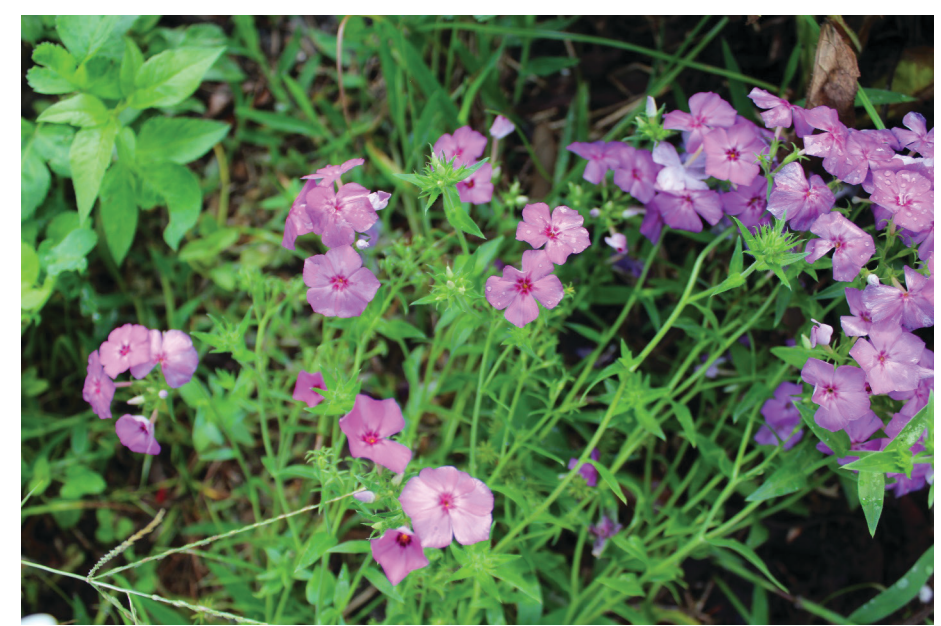

Figure 11. Phlox sp. growing after reseeding itself from a previous year. Credits: Tina Mclntyre, UF/IFAS

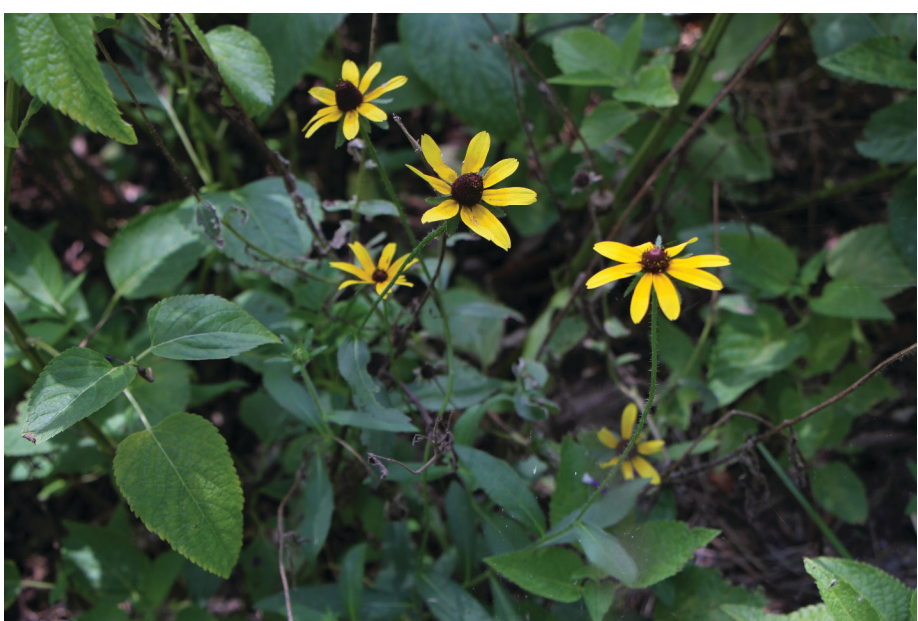

Figure 12. Rudbeckia fulgida growing in a cultivated governmental landscape.

Credits: Vincent Marcucci

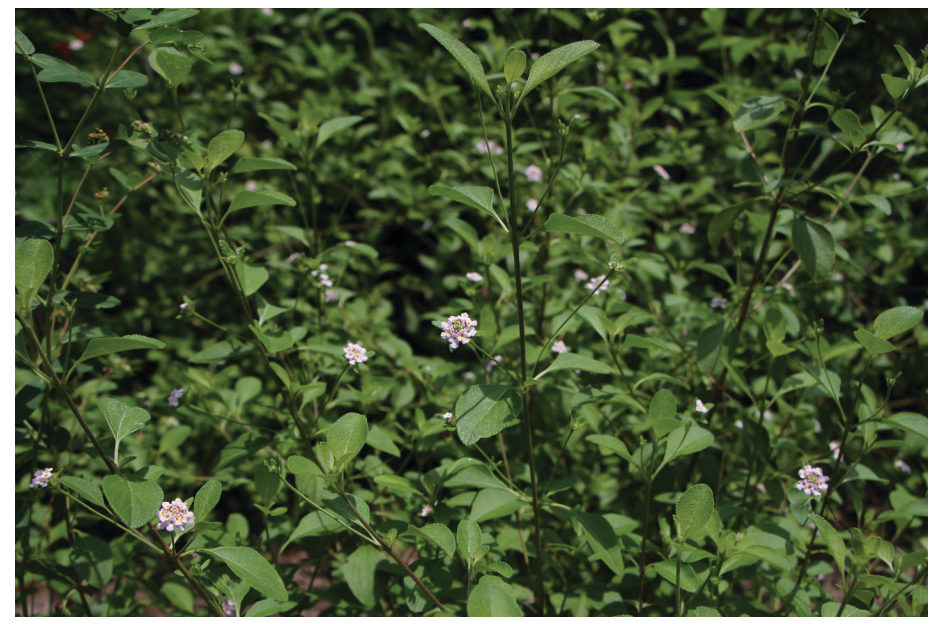

Figure 13. Lantana involucrata.

Credits: Vincent Marcucci

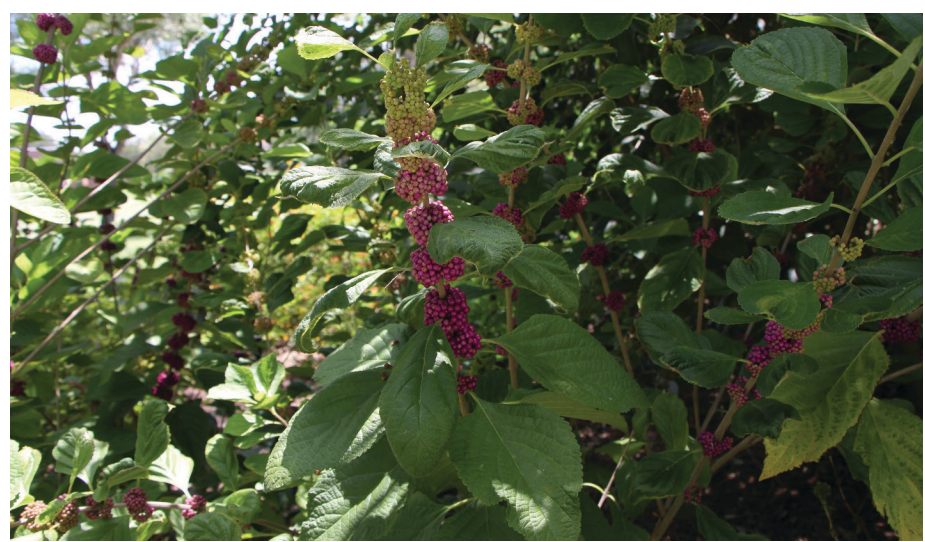

Figure 14. American beauty berry, Callicarpa americana, showcasing its beautiful purple berries.

Credits: Vincent Marcucci

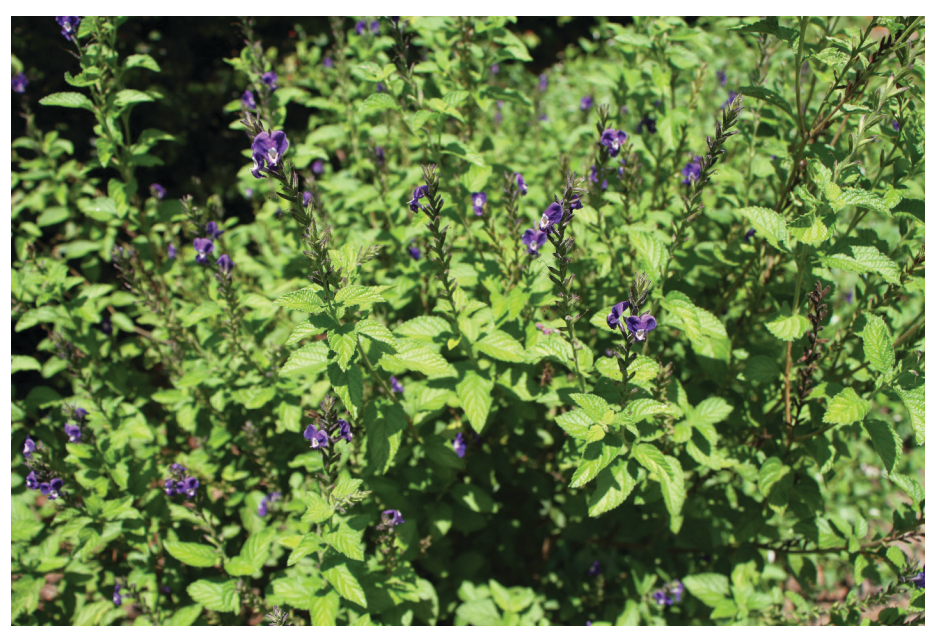

Figure 15. Purple porterweed, Stachytarpheta frantzii, a common spring bloomer of Florida's natural areas.

Credits: Vincent Marcucci

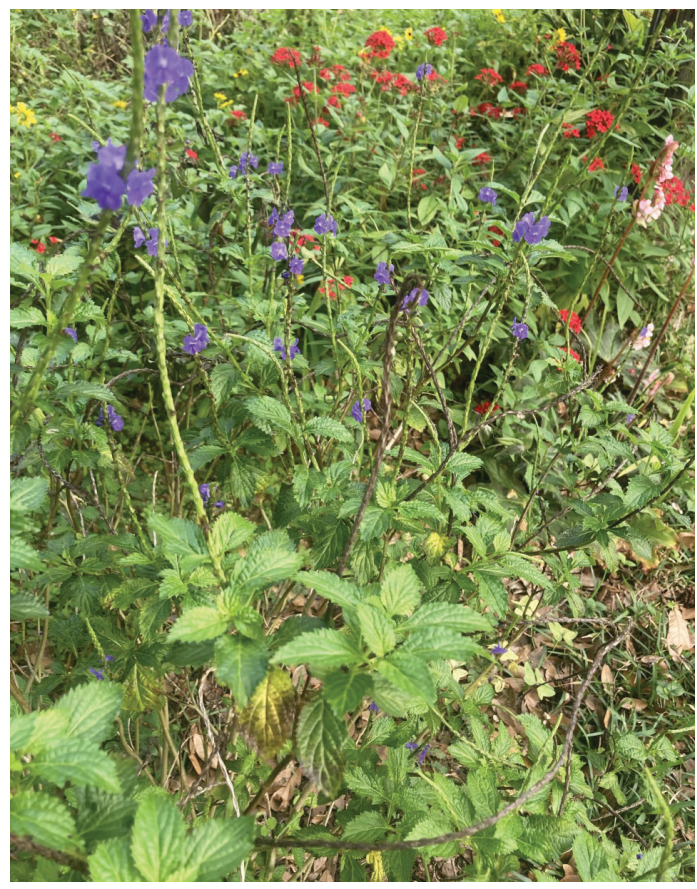

Figure 16. Stachytarpheta jamaicensis (purple) is showcased with Pentas lanceolata (red) and Helianthus debilis (yellow).

Credits: Tina McIntyre, UF/IFAS 
Table 1. This table lists selected Florida-friendly plants in order of bloom period: fall, spring, or year-round. Native status, USDA Zone, and $\mathrm{pH}$ are listed as well. N/A in the $\mathrm{pH}$ column means that the preferred $\mathrm{pH}$ was not available. An asterisk (*) on the binomial denotes a reseeding perennial. A dagger $(\dagger)$ on the binomial name of the plant signifies that the species serves as a host plant.

\begin{tabular}{|c|c|c|c|c|c|c|c|c|c|c|}
\hline Binomial & Common Name & Native & $\begin{array}{l}\text { USDA } \\
\text { Zone }\end{array}$ & pH & Wet & Dry & Sun & $\begin{array}{l}\text { Part- } \\
\text { Shade }\end{array}$ & Shade & P/A \\
\hline \multicolumn{11}{|c|}{ Fall Bloom } \\
\hline $\begin{array}{l}\text { Ampelaster carolinianus (a.k.a. } \\
\text { Symphyotricum carolinianum) }\end{array}$ & Climbing aster & Yes & $8 a-11$ & $5.1-6.5$ & $x$ & $x$ & $x$ & & & $P$ \\
\hline Asclepias incarnata $†$ & Swamp milkweed & Yes & $3 b-11$ & $6.5-8.0$ & $x$ & & $x$ & & & $P$ \\
\hline Asclepias perennis $\dagger$ & Aquatic milkweed & Yes & $6 a-9 b$ & $5.1-7.5$ & $x$ & & $x$ & $x$ & & $P$ \\
\hline Caesalpinia pulcherrima & Dwarf poinciana & No & $9 a-11$ & $6.1-7.8$ & & $x$ & $x$ & & & $P$ \\
\hline Calliandra haematocephala & Powderpuff tree & No & $9 a-11$ & $6.0-7.5$ & $x$ & $x$ & $x$ & $x$ & & $P$ \\
\hline $\begin{array}{l}\text { Callicarpa americana } \\
\text { (Figure 14) }\end{array}$ & American beautyberry & Yes & $6-10 b$ & $5.2-7.0$ & & $x$ & $\mathrm{x}$ & $\mathrm{x}$ & & $P$ \\
\hline $\begin{array}{l}\text { Carphephorus paniculatus (Figure } \\
\text { 9) }\end{array}$ & $\begin{array}{l}\text { Deer tongue/hairy } \\
\text { chaffhead }\end{array}$ & Yes & $8 a-9 b$ & $5.8-7.0$ & $x$ & $x$ & $x$ & & & $P$ \\
\hline Chamaecrista fasciculatat & Partridge pea & Yes & $3-9 b$ & $6.0-8.0$ & & $x$ & $x$ & & & $A$ \\
\hline Chrysopsis floridana & Florida goldenaster & Yes & $9 a-9 b$ & $5.5-7.0$ & & $x$ & $x$ & & & $P$ \\
\hline Chrysopsis mariana & Maryland goldenaster & Yes & $4 a-10 b$ & $5.1-7.5$ & $x$ & & $x$ & & & $P$ \\
\hline Chrysopsis subulata & Scrubland goldenaster & Yes & $8 a-11$ & $\mathrm{~N} / \mathrm{A}$ & & $x$ & $x$ & & & $P$ \\
\hline Conradina canescens & False rosemary & Yes & $8 a-9 b$ & $<6.0$ & & $x$ & $x$ & & & $P$ \\
\hline Echinacea purpureat & Purple coneflower & Yes & $3-8 b$ & $6.5-7.2$ & & $x$ & $x$ & $\mathrm{x}$ & & $P$ \\
\hline Heliotropium curassavicum & Seaside/salt heliotrope & Yes & $3 a-11$ & $6.5-8.5$ & $x$ & $x$ & $x$ & $x$ & & $\mathrm{P}$ \\
\hline Liatris spicata & Slender head blazing star & Yes & $8 a-10 b$ & $5.6-7.5$ & $x$ & $x$ & $x$ & & & $P$ \\
\hline Monarda punctata (Figure 3)† & $\begin{array}{l}\text { Spotted bee balm; } \\
\text { horsemint }\end{array}$ & Yes & $3 a-8 b$ & $6.1-7.8$ & & $x$ & $\mathrm{x}$ & & & $P$ \\
\hline Muhlenbergia capillaris & Pink muhly grass & Yes & $7 a-11$ & $5.8-6.8$ & & $x$ & $x$ & $x$ & & $\mathrm{P}$ \\
\hline Ocimum basilicum & Sweet basil & No & $2 a-11$ & $5.1-8.5$ & & $x$ & & $x$ & $x$ & $\mathrm{P}$ \\
\hline Oenothera lindheimeri & $\begin{array}{l}\text { Whirling butterflies/ } \\
\text { beeblossom }\end{array}$ & No & $5-9 b$ & $6.1-7.8$ & & $x$ & $\mathrm{x}$ & & & $P$ \\
\hline Palafoxia integrifolia & Coastal plain palafox & Yes & $9 a-10 b$ & $4.5-7.5$ & & $x$ & $x$ & & & $\mathrm{P}$ \\
\hline Passiflora incarnata† & Purple passion vine & Yes & $5 a-10 b$ & $6.1-7.5$ & & $x$ & $x$ & & & $P$ \\
\hline Pityopsis graminifolia & Narrow leaf silk grass & No & $8 a-11$ & $5.8-7.0$ & & $x$ & $\mathrm{x}$ & & & $P$ \\
\hline Polygonella polygama & Jointweed & Yes & $9 a-10 b$ & $4.5-5.5$ & & $x$ & $x$ & $x$ & & $\mathrm{P}$ \\
\hline Psychotria nervosa & Wild coffee & Yes & $9 a-11$ & $6.1-7.5$ & & $x$ & $x$ & & & $P$ \\
\hline Silphium asteriscus* & Starry rosinweed & Yes & $8 a-10 b$ & $5.1-7.6$ & & $x$ & $x$ & $x$ & & $P$ \\
\hline Rudbeckia hirta (Figure 10) & Black-eyed Susan & Yes & $8 a-10 b$ & $6.0-7.0$ & & $x$ & $x$ & & & $A$ \\
\hline Rudbeckia laciniata & $\begin{array}{l}\text { Green headed/cutleaf } \\
\text { coneflower }\end{array}$ & Yes & $8 a-8 b$ & $4.5-7.0$ & $x$ & & $x$ & $x$ & & $P$ \\
\hline Ruellia caroliniensist & Carolina wild petunia & Yes & $6 a-10 b$ & $7.9-8.5$ & $x$ & $x$ & $x$ & $x$ & $x$ & $P$ \\
\hline Salvia azurea & Azure blue sage & Yes & $5-9 b$ & $6.1-7.8$ & & $x$ & $x$ & & & $P$ \\
\hline Salvia miniata & Belize sage & No & $9 a-11$ & $6.1-7.8$ & & $x$ & $x$ & & & $P$ \\
\hline Senna ligustrina† & Privet senna & Yes & $9 a-11$ & $6.1-7.8$ & & $x$ & $x$ & & & $\mathrm{P}$ \\
\hline $\begin{array}{l}\text { Senna mexicana var. chapmanii† } \\
\text { (Figure 2) }\end{array}$ & Bahama senna & Yes & $10 a-11$ & $>7.0$ & & $x$ & $x$ & & & $P$ \\
\hline Serenoa repenst & Saw palmetto & Yes & $6 a-11$ & $5.6-6.5$ & $x$ & $x$ & $x$ & & & $P$ \\
\hline
\end{tabular}




\begin{tabular}{|c|c|c|c|c|c|c|c|c|c|c|}
\hline Binomial & Common Name & Native & $\begin{array}{l}\text { USDA } \\
\text { Zone }\end{array}$ & pH & Wet & Dry & Sun & $\begin{array}{l}\text { Part- } \\
\text { Shade }\end{array}$ & Shade & P/A \\
\hline Solidago odora*† & Sweet goldenrod & Yes & $8 b-11$ & $5.6-7.8$ & & $x$ & $x$ & & & $P$ \\
\hline Solidago sempervirens*† & Seaside goldenrod & Yes & $3 a-8 a$ & $5.5-7.5$ & & $x$ & $x$ & $x$ & & $P$ \\
\hline Sorghastrum secundum $\dagger$ & Lopsided Indiangrass & Yes & $8 a-9 b$ & $6.1-6.5$ & & $x$ & $x$ & & & $P$ \\
\hline Spartina bakeri & Sand cordgrass & Yes & $8 a-10 b$ & $6.8-7.2$ & & $x$ & $x$ & & & $P$ \\
\hline Stokesia laevis & Stoke's aster & Yes & $8 a-10 b$ & $5.6-7.0$ & & $x$ & $x$ & $x$ & & $P$ \\
\hline Trichostema dichotomum & Blue curls & Yes & $8 a-11$ & $\mathrm{~N} / \mathrm{A}$ & & $x$ & $x$ & & & A \\
\hline Tripsacum floridanum $\dagger$ & Dwarf fakahatchee grass & Yes & $8 a-10 b$ & $7.9-8.5$ & & $x$ & $x$ & $x$ & & $P$ \\
\hline Vernonia angustifolia & Narrow-leaf ironweed & Yes & $8 a-9 b$ & $5.1-7.5$ & & $x$ & $x$ & $x$ & & A \\
\hline \multicolumn{11}{|c|}{ Spring Bloom } \\
\hline Asclepias incarnata† & Swamp milkweed & Yes & $3 b-11$ & $6.5-8.0$ & $x$ & & $x$ & & & $P$ \\
\hline Asimina obovatat & Flag pawpaw & Yes & $8 a-10 b$ & $6.0-6.8$ & & $x$ & $x$ & $x$ & & $P$ \\
\hline Asimina pygmaeat & Dwarf pawpaw & Yes & $7 a-10 b$ & $5.0-7.0$ & $x$ & $x$ & $x$ & $x$ & & $P$ \\
\hline Caesalpinia pulcherrima & Dwarf poinciana & No & $9 a-11$ & $6.1-7.8$ & & $x$ & $x$ & $x$ & & $\mathrm{P}$ \\
\hline Calamintha ashei & Ashe's calamint & Yes & $8 a-9 b$ & $6.1-7.8$ & & $x$ & $x$ & & & $P$ \\
\hline Calliandra haematocephala & Powderpuff tree & No & $9 a-11$ & $6.0-7.5$ & & $x$ & $x$ & & & $P$ \\
\hline Callicarpa americana & American beautyberry & Yes & $6-10 b$ & $5.2-7.0$ & $x$ & $x$ & $x$ & $x$ & & $P$ \\
\hline Coccoloba uvifera & Seagrape & Yes & $9 a-11$ & $4.5-7.2$ & & $x$ & $x$ & $x$ & & $P$ \\
\hline Coreopsis lanceolata & Large-flower tickseed & Yes & $4-9 b$ & $6.0-7.0$ & $x$ & $x$ & $x$ & $x$ & $x$ & A \\
\hline Duranta erecta & Sapphire showers duranta & No & $9 b-11$ & $5.6-7.5$ & & $x$ & $x$ & $x$ & $x$ & $P$ \\
\hline Dyschoriste oblongifoliat & Oblong snakeherb & Yes & $8 a-11$ & $6.0-7.2$ & $x$ & $x$ & $x$ & $x$ & & $P$ \\
\hline Heliotropium curassavicum & Seaside/salt heliotrope & Yes & $3 a-11$ & $6.5-8.5$ & & $x$ & $x$ & $x$ & & $P$ \\
\hline Ilex glabrat & Gallberry & Yes & $8-10 a$ & $4.5-6.5$ & & $x$ & $x$ & $x$ & $x$ & $P$ \\
\hline Lonicera sempervirenst & Coral honeysuckle & Yes & $8-9 b$ & $4.5-7.2$ & $x$ & & & $x$ & & $P$ \\
\hline Magnolia grandiflora & Southern magnolia & Yes & $8-9 b$ & $4.5-7.2$ & $\mathrm{x}$ & $\mathrm{x}$ & $x$ & $x$ & & $P$ \\
\hline Magnolia virginiana & Sweet bay magnolia & Yes & $8-9 b$ & $4.5-6.5$ & & $x$ & $x$ & $x$ & $x$ & $P$ \\
\hline Myrcianthes fragrans (Figure 7) & Simpson's stopper & Yes & $10 a-11$ & $7.9-8.2$ & & $x$ & $x$ & & & $P$ \\
\hline Oenothera simulanst & Southern beeblossom & Yes & $7 a-11$ & $\mathrm{~N} / \mathrm{A}$ & & $x$ & $x$ & $x$ & & $P$ \\
\hline Passiflora incarnata† & Purple passion vine & Yes & $5 a-10 b$ & $6.1-7.5$ & & $x$ & $x$ & & & $\mathrm{P}$ \\
\hline Phlox divaricata & $\begin{array}{l}\text { Wild blue phlox/phlox } \\
\text { woodland }\end{array}$ & Yes & $3 a-8 b$ & $6.8-7.2$ & & $x$ & $x$ & $x$ & & A \\
\hline Phlox drummondii & Annual phlox & No & $2 a-11$ & $6.1-7.2$ & & $x$ & $x$ & & & $A$ \\
\hline Psychotria nervosa & Wild coffee & Yes & $9 a-11$ & $6.1-7.5$ & & $x$ & $x$ & $x$ & & $P$ \\
\hline $\begin{array}{l}\text { Rhododendron austrinum } \\
\text { or Rhododendron canescens }\end{array}$ & Azalea & Yes & $8-10 b$ & $4.5-6.5$ & & $x$ & $x$ & $x$ & & $\mathrm{P}$ \\
\hline Rudbeckia hirta & Black-eyed Susan & Yes & $8 a-10 b$ & $6.0-7.0$ & & $x$ & $x$ & $x$ & $x$ & $A$ \\
\hline Ruellia caroliniensist & Carolina wild petunia & Yes & $6 a-10 b$ & $7.9-8.5$ & $x$ & & $x$ & & & $P$ \\
\hline Scutellaria integrifolia* & Skullcap & Yes & $6 b-9 a$ & $4.8-5.2$ & & $x$ & $x$ & $x$ & & $\mathrm{P}$ \\
\hline Silphium asteriscus* & Starry rosinweed & Yes & $8 a-10 b$ & $5.1-7.6$ & & $x$ & $x$ & & & $\mathrm{P}$ \\
\hline Stachytarpheta frantzii (Figure 15) & $\begin{array}{l}\text { Large-flowered purple } \\
\text { porterweed }\end{array}$ & No & $9 b-11$ & $6.1-7.8$ & & $\mathrm{x}$ & $x$ & $\mathrm{x}$ & & $P$ \\
\hline Stachytarpheta jamaicensis & Porterweed & Yes & $8 b-11$ & $6.1-7.8$ & $x$ & $\mathrm{x}$ & $x$ & $x$ & $x$ & $\mathrm{P}$ \\
\hline Trichostema dichotomum & Blue curls & Yes & $8 a-11$ & $\mathrm{~N} / \mathrm{A}$ & & $\mathrm{x}$ & $x$ & $\mathrm{x}$ & & $P$ \\
\hline Tripsacum floridanum $\dagger$ & Dwarf fakahatchee grass & Yes & $8 a-10 b$ & $7.9-8.5$ & & $\mathrm{x}$ & $x$ & & & A \\
\hline
\end{tabular}




\begin{tabular}{|c|c|c|c|c|c|c|c|c|c|c|}
\hline Binomial & Common Name & Native & $\begin{array}{l}\text { USDA } \\
\text { Zone }\end{array}$ & pH & Wet & Dry & Sun & $\begin{array}{l}\text { Part- } \\
\text { Shade }\end{array}$ & Shade & P/A \\
\hline Vaccinium darrowi & Little blueberry & Yes & $8-10 b$ & $<7.0$ & & $x$ & $x$ & $x$ & & $P$ \\
\hline Vaccinium myrsinities & Shiny blueberry & Yes & $8 a-11$ & $<7.0$ & & $x$ & $x$ & $x$ & & $P$ \\
\hline Viburnum obovatum & Walter's viburnum & Yes & $8-10 b$ & $4.5-8.0$ & & $x$ & $x$ & $x$ & & $P$ \\
\hline Viburnum odoratissimum & Sweet viburnum & No & $8 b-10 a$ & $4.5-8.0$ & & $x$ & $x$ & $x$ & & $P$ \\
\hline \multicolumn{11}{|c|}{ Year-Round Bloom } \\
\hline Berlandiera subacaulis & Florida greeneyes & Yes & $8 b-11$ & $5.1-7.5$ & $x$ & $x$ & $x$ & $x$ & & $P$ \\
\hline Calliandra emarginata & Dwarf powderpuff & No & $9 a-11$ & $7.9-8.5$ & & $x$ & $x$ & $\mathrm{x}$ & & $P$ \\
\hline Funastrum clausum† & White twinevine & Yes & $9 b-11$ & $6.0-8.5$ & $x$ & $x$ & $x$ & $x$ & & $P$ \\
\hline Gaillardia pulchella (Figure 5) & Indian blanket flower & Yes & $8 a-11$ & $7.0-8.5$ & & $x$ & $x$ & & & A \\
\hline Glandularia maritima & Beach verbena & Yes & $9 a-11$ & $\begin{array}{c}\text { Calcareous } \\
\text { but } \\
\text { adapable }\end{array}$ & & $\mathrm{x}$ & $\mathrm{x}$ & $x$ & & $P$ \\
\hline Hamelia patens & Firebush & Yes & $9 a-11$ & $5.5-8.2$ & & $x$ & $x$ & $x$ & & $P$ \\
\hline $\begin{array}{l}\text { Helianthus debilis (Figures 1, 6, and } \\
\text { 16) }\end{array}$ & Dune sunflower & Yes & $8 b-10$ & $5.5-8.2$ & & $x$ & $x$ & $x$ & & $P$ \\
\hline $\begin{array}{l}\text { Heliotropium angiospermum* } \\
\text { (Figure 2) }\end{array}$ & Scorpion tail & Yes & $8 a-9 b$ & $7.9-8.5$ & & $\mathrm{x}$ & $x$ & $x$ & & $P$ \\
\hline Heliotropium polyphyllum & Pineland heliotrope & Yes & $8 a-11$ & $6.1-6.8$ & & $x$ & $x$ & $x$ & & $P$ \\
\hline Lantana depressa & $\begin{array}{l}\text { Florida lantana or gold } \\
\text { lantana/cream carpet }\end{array}$ & Yes & $10 a-11$ & $>7.2$ & & $x$ & $x$ & & & $P$ \\
\hline Lantana involucrata (Figure 13) & Buttonsage, wild lantana & Yes & $8 a-11$ & $6.6-7.3$ & & $x$ & $x$ & & & $P$ \\
\hline Passiflora suberosat & Corkystem passionflower & Yes & $9 a-11$ & $7.5-8.5$ & & $x$ & $x$ & & & $P$ \\
\hline Pentas lanceolata (Figures 4 and 8) & Egyptian starcluster & No & $10 a-11$ & $6.5-7.1$ & & $x$ & $x$ & $x$ & & $\mathrm{P}$ \\
\hline Phyla nodiflorat & Frogfruit & Yes & $6 a-11$ & $4.5-8.0$ & $x$ & $x$ & $\mathrm{x}$ & $x$ & $x$ & $P$ \\
\hline Rivina humilis* & Rouge plant, pigeon berry & Yes & $8 a-10 b$ & $6.1-7.8$ & & $x$ & $x$ & $x$ & & $P$ \\
\hline Salvia leucantha & Mexican sage & No & $4 a-12$ & $7.6-9.0$ & & $x$ & $x$ & & & $P$ \\
\hline Salvia longispicata $\times$ farinacea & Mystic spires blue sage & No & $7-10 a$ & $6.1-7.8$ & & $\mathrm{x}$ & $x$ & $x$ & $x$ & $P$ \\
\hline Stachytarpheta jamaicensis & Blue porterweed & Yes & $8 b-11$ & $6.1-7.8$ & & $\mathrm{x}$ & $\mathrm{x}$ & $x$ & & $P$ \\
\hline Zamia pumila† & Coontie & Yes & $8 b-11$ & $4.5-8.0$ & & $x$ & $x$ & $x$ & $x$ & $P$ \\
\hline
\end{tabular}

